\title{
Foreign Banks Lending During The Crisis: Do Profitability and Liquidity Matter?
}

\author{
Rizky Yudaruddin

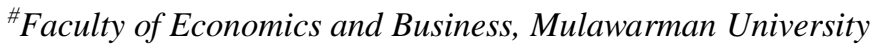 \\ Samarinda, Indonesia \\ rizky. yudaruddin@feb. unmul.ac.id
}

\begin{abstract}
The purpose of this study is to assess the impact of the global economic crisis in 2008-2009 on loan growth in foreign banks in Indonesia. Using Indonesian banking industry data, I constructed a panel of 1,372 bank-year observations for 98 banks in Indonesia, which includes 20 bank-year observations for foreign-owned banks. The analysis of data in this research used data panel regression method. The results show that the loan growth of foreign bank is stable during crisis because those foreign banks in Indonesia serve as more 'crisis-mitigating impact' for their respective parent bank. In addition, profitability and liquidity are found to weaken the effect of crisis on the loan growth, as more foreign banks being more cautious in lending during the crisis.
\end{abstract}

Keywords - component; Foreign Bank, Credit Growth, Crisis, Liquidity and Profitability

\section{INTRODUCTION}

The global economic crisis that occurred in 2008 and 2009 has affected the banking industry in Indonesia [1]. Based on Banking Supervision Report Year 2009, there are two important things that happen to the banking industry, especially in relation to credit growth. Firstly, credit growth slows due to the decrease of foreign currency credit. Foreign currency loans experienced negative growth of -17.4 percent. This condition happened due to the appreciation of the rupiah against the US dollar and the decline in export and import activities. Second, the growth of consumption credit and working capital has decreased. Credit growth, especially for consumption activity, has experienced the lowest point in the last 3 years. The same thing also happened in the growth of working capital credit which decreased from growth during the previous two years reached 28 percent to 2.7 percent [2].

The impact of the crisis became the object of many studies, especially those related to economics. Based on the studies conducted by [3], [4], [5], [6], [7], the global economic crisis is found negatively affected the loan growth. The finding indicates that the global economic crisis has influenced the growth of bank loan. Consequently, banks behavior is more likely to lower its lending and that has caused the decrease of loan growth. The study conducted by [8] found the impact of the crisis on the Economic of East Asia region, during East Asia financial crisis in 1997 and the global financial crisis of 2008. There was a difference between the two crises, in which the 1997 East Asia financial crisis provided knowledge for each country to be better prepared when the 2008 global financial crisis hit, compared with crisis in 1997.

The effect of banks high profitability weakens the impact of global economic crisis on loan growth. This indicates that the behavior of banks is more likely to improve the lending. [7] suggests that the interaction of profitability with the crisis on loan growth is positive and statistically significant. As a result, increasing the profitability will weakenthe impact of the crisis on bank lending. High profitability of banks during the crisis has enable banks to maintain its asset quality and earnings, as well as increasing the amount of lending. In contrast, a research by [9] argued that profitability expressed a negative sign. The study does not mean that the high profitability able to reduce the impact of the crisis on bank lending, so banks tend to decrease lending.

Several studies involving liquidity as their variable indicated that the higher the liquidity of the bank, the weaker the impact of the global economic crisis on the growth of loan. Based on [14] the need to increase the resilience of banks to liquidity risk due to the composition of the bank sourced from short-term funding sources of funding via the market is that it limits banks' ability to supply new loans during crisis. As a research conducted by [9], liquidity showed a positive effect in connection with loan crisis. This fact shows that the bank's liquidity increased during the pre-crisis. As a consequence, when the crisis hit, banks have already owned a high 
supply of funds and they do not need to worry about the impact of the crisis generated, which in turn have a positive impact that will weaken the impact of the global economic crisis. This finding than become references for banks tendencies to increase its lending. However, the finding of the study is different with [4] which in contratst explained that liquidity has shown negative effect on its connection with the loan crisis. This opposing result proposed that high liquidity owned by banks are not able to reduce the impact of the global crisis on bank lending, which consequently affects the banks to more likely to lower its lending, which is in line with the declining ability of banks to meet short-term obligations.

The purpose of this study is to assess the impact of the global economic crisis in 2008-2009 on the behavior of loan in foreign banks in Indonesia. Specifically, this study focused on two main points: this study examined the foreign and joint venture banks in Indonesia. The second one, this study examined the condition of banks during crisis through the observation of interaction between profitability and liquidity variables to see how profitability and liquidity reduce the impact of global economic crisis on bank lending.

\section{LITERATURE REVIEW}

\section{A. Crisis and Growth Credit}

The impact of the crisis on credit growth is expected to be negative. A study by [4] suggested that the global economic crisis has significant negative effect on loan growth. This situation means that the global economic crisis has impact on the growth of bank loan. As a result of this, the behavior is more likely for banks to lower its lending so loan growth will also decrease. However, other research showed in line results as conducted by [3], [5], [6], [7] that revealed the global economic crisis has significant negative effect on loan growth, which indicates that during the crisis, banks lower their lending.

\section{B. Profitability, Crisis and Credit Growth}

Banks profitability can be measured by the ratio of return on assets. [10], [3], [5], [7], [11] describe that profitability showed positive signs. The condition indicates that during high profitability, bank is more likely to improve loan growth, which cuase the increasing percentage of returns that will be received by the bank. Some previous studies show that high bank profitability has an impact on weakening the effect of global economic crisis on loan growth. The study by [12] explains that profitability showed a negative sign for the relations with the global economic crisis lending. The study means that high profitability of bank is able to weaken the impact of the crisis on the loan behavior, so that banks tend to increase lending which would also increase the loan growth. However, different results were found in the study by [7] which claimed that the profitability showed positive signs on the relationship with loan growth during crisis. The study indicates that the increased profitability of the bank is not able to reduce the impact of the crisis on loan growth.

\section{Liquidity, Crisis and Credit Growth}

Banks that have higher level of liquidity will tend to increase lending. Based on previous studies, the higher the liquidity the weaker the impact of global economic crisis on loan growth. According to [4], liquidity shows a negative result on the relationship of crisis with loan growth. This finding suggests that when bank's liquidity has increased during the precrisis, the banks already have sufficient capital funds during crisis. Consequently, they do not need to be worried about the impact of the crisis, which would also weaken the impact of the global economic crisis on the bank concerned. It becomes a reference for bank to remain increasing its lending. But a study by [9] explained that the liquidity showed a positive and significant effect on the relationship with the loan during the crisis. This result indicates that the high liquidity owned by banks are not able to reduce the impact of global crisis on bank lending, so banks are more likely to decrease lending

\section{METHOD}

This study adapts the model conducted by [4], [9], [7], which examined the impact of economic crisis on loan growth. I also encounter with the crisis of liquidity and profitability. The studies also used controlled variables: deposits, size, interest rate and GDP [4], [9], [5], [7]. This study specifically examined the impact of the crisis on foreign and the joint venture banks during 2003-2012 that operationally exist with the following model: 
GLOAN $_{\mathrm{i}, \mathrm{t}}=\alpha+\beta_{\mathrm{k}}$ CRISIS $_{\mathrm{t}}+\beta_{\mathrm{k}}$ CRISIS $^{\mathrm{x}}$ FOREIGN $_{\mathrm{i}, \mathrm{t}}+$ $\beta_{\mathrm{k}}$ CRISIS $^{\mathrm{x}}$ FOREIGN ${ }^{\mathrm{x}} \mathrm{PROF}_{\mathrm{i}, \mathrm{t}}$ $\beta_{\mathrm{k}}$ CRISIS $^{\mathrm{x}}$ FOREIGN ${ }^{\mathrm{x}} \mathrm{LIQ}_{\mathrm{I}, \mathrm{t}}+\beta_{\mathrm{k}} \sum$ Bank Specific $_{\mathrm{i}, \mathrm{t}}+\beta_{\mathrm{k}} \sum$ Macroeconomic $_{\mathrm{t}}+\varepsilon_{\mathrm{i}, \mathrm{t}}$

where the dependent variable is the CREDIT GROWTH of bank bank $i$ in year t. CRISIS which takes the value of 1 for the years 2008-2010 and zero otherwise. CRISIS*FOREIGN is interaction of foreign with the crisis to capture the impact of foreign bank. While CRISIS ${ }^{\mathrm{x}}$ FOREIGN ${ }^{\mathrm{x}} \mathrm{PROF}$ and CRISIS ${ }^{\mathrm{x}}$ FOREIGN ${ }^{\mathrm{x}} \mathrm{LIQ}$ are interaction of foreign with the crisis, profitability and liqudity to capture the impact profitability and liqudity of foreign bank during crisis on lending behavior. In this model, I also include bank-specific control variables: prfotability, liqudity, capital and the size of company (SIZE). Profitability is a ratio of return to total asset; Liquidity is measured by Loan to Deposit Ratio. I use the ratio of equity to assets (EA) to proxy the capital variable. Size is measured by lognatura total asset. The variables of capital and size are expected to be positive. It means that the variables may push banks to be expansive on credit growth. During crisis, [chow] find that banks have a higher deposit base and stronger capitalization that will have a positive effect on credit growth. Reference [5], [16] found a significant positive effect on lending behavior bank. I also include macroeconomic variables interest rate, Gross Domestic Product (GDP) growth and inflation. Signs of economic crisis can also be seen from the decline in GDP of a country. For GDP variable, [6], [15], [16], [17], found a significant positive effect that is the increasing of GDP led to the increase of lending.Interest rate is measured by average working capital loan interest rates. Studies by [5], [6] found that interest rate towards credit lending is positive. Inflation is masusred by annual inflation in Indonesia.

Using Indonesian banking industry data, I constructed a panel of 1,372 bank-year observations for 98 banks in Indonesia. The sample includes 20 bank-year observations for foreign-owned banks. The analysis of data in this research used data panel regression method. Selection of data panel regression model was tested with chow test and Hausman test. As a result, PLS models, Fixed Effect or Random Effect [13].

\section{RESULT AND DISCUSSION}

Table 1 provides basic descriptive statistics for all variabel. Overall the mean values of all variables are smaller than the standard deviation except variables GLOAN and PROF. The data show that the mean and the standard deviation value for GLOAN are 29.64074 and 72.91578 respectively. The maximum and minimum values of PROF is 57 and -152.990 , respectively, and the standar deviation is 5.016803 .

TABLE 1.

DESCRIPTIVE STATISTICS OF VARIABLES

\begin{tabular}{|c|r|r|r|r|r|r|}
\hline Variabel & Mean & \multicolumn{1}{c|}{ Median } & \multicolumn{1}{c|}{ Maximum } & \multicolumn{1}{c|}{ Minimum } & \multicolumn{1}{l|}{ Std. Dev. } & Observations \\
\hline GLOAN & 29.64074 & 20.74654 & 1131.652 & -97.4643 & 72.91578 & 1372 \\
\hline CRISIS & 0.142857 & 0.000000 & 1.000000 & 0.000000 & 0.350055 & \\
\hline PROF & 2.349168 & 2.330000 & 57.00000 & -152.990 & 1372 \\
\hline LIQ & 84.90365 & 81.14000 & 620.2500 & 1.000000 & 48.72273 & \\
\hline EA & 0.143682 & 0.115890 & 2.999623 & -0.03702 & 0.131852 & 1372 \\
\hline SIZE & 15.36089 & 15.27654 & 20.55603 & 9.875242 & 1.853797 & 1372 \\
\hline GDP & 15.99936 & 14.05350 & 25.25501 & 9.227886 & 5.499438 & \\
\hline INF & 14.97574 & 14.87920 & 20.49003 & 5.060000 & 1.915489 & 1372 \\
\hline INTR & 13.85474 & 13.20500 & 18.25000 & 11.65750 & 1.808715 & \\
\hline
\end{tabular}

Tabel 2. presents information on the degree of correlation between the independent variables used in multivariate regression analysis. Matrix shows

that in general the correlation between the explanatory variables is not strong multicolinearity problems occur.

TABLE 2

CORRELATION MATRIX FOR THE EXPLANATORY VARIABLES

\begin{tabular}{|c|c|c|c|c|c|c|c|c|}
\hline & CRISIS & ROA & LIQ & EA & SIZE & GDP & INF & INTR \\
\hline CRISIS & 1.000000 & & & & & & & \\
\hline PROF & 0.008611 & 1.000000 & & & & & & \\
\hline
\end{tabular}


TABLE 2, CONT

\begin{tabular}{|c|r|r|r|r|r|r|r|r|}
\hline LIQ & 0.003010 & 0.009023 & 1.000000 & & & & \\
\hline SOL & 0.087223 & 0.029051 & 0.200448 & 1.000000 & & & \\
\hline SIZE & -0.005812 & 0.038437 & 0.057979 & -0.324116 & 1.000000 & & & \\
\hline GDP & 0.242932 & 0.054733 & -0.135589 & 0.013800 & -0.188657 & 1.000000 & & \\
\hline INF & -0.061832 & 0.023244 & -0.085094 & -0.030669 & -0.153451 & 0.543748 & 1.000000 & \\
\hline INTR & 0.135534 & 0.067204 & -0.211830 & -0.048819 & -0.285645 & 0.661523 & 0.519435 & 1.000000 \\
\hline
\end{tabular}

The estimation of the crisis impact on growth loan of foreign banks in Indonesia in 2003-2012 is using data panel regression. The analysis results to determine the best model for this study, was done

with chow test and Hausman test, and as it can be seen that the proper regression model are PLS models, Fixed Effect or Random Effect.

TABLE 3 .

ESTIMATIONS RESULTS OF PANEL REGRESSION

\begin{tabular}{|c|c|c|c|c|c|c|}
\hline \multirow[b]{2}{*}{ Explanatory Variables } & \multicolumn{3}{|c|}{ (1) } & \multicolumn{3}{|c|}{ (2) } \\
\hline & Pooled OLS & Fixed Effects & $\begin{array}{l}\text { Random } \\
\text { Effects }\end{array}$ & Pooled OLS & Fixed Effects & $\begin{array}{l}\text { Random } \\
\text { Effects }\end{array}$ \\
\hline Constant & $30.70763 * * *$ & $30.70763 * * *$ & $30.70763 * * *$ & $102.2634 * * *$ & $101.9375 * * *$ & $102.8027 * * *$ \\
\hline CRISIS & -8.996137 & -7.998542 & -8.642591 & -9.769500 & -9.248616 & -9.365776 \\
\hline CRISIS ${ }^{x}$ FOREIGN & $98.18632 * * *$ & $77.29695 * * *$ & $90.74539 * * *$ & $107.8490 * * *$ & $81.21248 * * *$ & $101.1102 * * *$ \\
\hline CRISIS $^{x}$ FOREIGN ${ }^{x}$ LIQ & $-0.439739 * * *$ & $-0.351197 * * *$ & $-0.408231 * * *$ & $-0.537090 * * *$ & $-0.358322 * * *$ & $-0.502233 * * *$ \\
\hline CRISIS $^{\times}$FOREIGN ${ }^{\times}$PROF & $-12.32779 * * *$ & $-10.47428^{*}$ & $-11.66418 * * *$ & $-11.50322 * * *$ & $-9.134181 * * *$ & $-10.94947 * * *$ \\
\hline LIQ. & & & & $0.071960^{*}$ & $0.237304 * * *$ & $0.100331 * *$ \\
\hline PROF. & & & & -0.818603 & -0.430206 & -0.744728 \\
\hline EQ & & & & -0.263077 & $-44.00209 * *$ & -9.880336 \\
\hline SIZE & & & & $-3.570799 * * *$ & $-4.504421 * * *$ & $-3.738680 * * *$ \\
\hline INTR & & & & $-2.957395^{*}$ & -2.560661 & $-2.907133^{*}$ \\
\hline GDP & & & & 0.763711 & $0.848127 *$ & 0.781480 \\
\hline INF & & & & 1.070874 & 0.939091 & 1.046918 \\
\hline R-squared & 0.010468 & 0.119711 & 0.009307 & 0.027006 & 0.136889 & 0.024956 \\
\hline Adjusted R-squared & 0.007572 & 0.049704 & 0.006409 & 0.019131 & 0.063025 & 0.017064 \\
\hline F-statistic & 3.615118 & 1.709988 & 3.210719 & 3.429133 & 1.853258 & 3.162093 \\
\hline Prob(F-statistic) & 0.006135 & 0.000031 & 0.012337 & 0.000101 & 0.000001 & 0.000304 \\
\hline Durbin Watson & 1.638905 & 1.841377 & 1.712170 & 1.654806 & 1.842963 & 1.705954 \\
\hline Chow test statistic & & 0.0002 & & & 0.0001 & \\
\hline Hausman test statistic & & & 0.7003 & & & 1.0000 \\
\hline Number of obs & 1372 & 1372 & 1372 & 1372 & 1372 & 1372 \\
\hline
\end{tabular}

The impact of the crisis on the loan behavior of foreign bank in Indonesia is presented in Table 3. Results showed the crisis has a positive sign and significant to the loan behavior of foreign banks in Indonesia. These results are in contrast to studies by [3], [5], [6], [7], which states that the global economic crisis has significant negative effect on loan growth. This means that the global financial crisis in 2008-2009 has impacted foreign banks, whereas banks behavior is to increase distributed credit because those foreign banks in Indonesia serve as more 'crisis-mitigating impact' for their respective parent bank.

The existence of a significant positive sign indicates that during the crisis, foreign banks actually increase the loan. This indicates that loan growth is stable during the crisis because of the foreign banks' parent bank is experiencing economic contraction characterized by a decrease in loan portfolio in the home country, so that loan from parent banks channeled to the foreign banks in host country. These results are consistent with research by [5], [6], which showed that during the crisis, foreign banks increase the lending for foreign banks in host country. This suggests that subsidiaries have a crisis-mitigating impact on host economies, especially when the source of the shock emanates from the strains in the financial conditions of global parent banks.

During crisis, particularly in foreign banks, profitability and liquidity weaken the crisis influence on the loan behavior. Foreign banks during crisis 
reduces the amount of outstanding loans in the event of an increase in profitability and liquidity. This shows more foreign banks cautiousness in lending during the crisis, thus increasing profitability and liquidity are not direct response by foreign banks to increase lending. These results differ from previous studies by [7], [9] that explains liquidity and profitability has positive and significant impact on the relationship with loan griwth during crisis.

For the control variables, size variable showed a significant positive sign, which means an increase in total asset of banks will increase lending. This is because loan comes from deposits collected by the bank. this study are consistent with findings [6], and [16] that deposit and size variable have significant positive effect on lending behaviore bank

The interest rate variable also showed a significant negative sign. It means that interest rate did not have any effect on bank behavior in decreasing the amount of credit. This result has different with previous studies by [5], [6], and [7]. This condition happened because bank behavior experienced high interest rate to get significant profit margin. Therefore, even though Bank Indonesia has decreased BI rate, the decrease was not followed by the decrease in credit rate interest. And that is why, banks in Indonesia has the highest Net Inters Margin in Southeast Asian. Bank will increase its credit distribution to get above average profit even though BI rate is decreasing. GDP variable is positive but not significant to the behavior of loan.

\section{CONCLUSION}

Based on the analysis on the growth loan of foreign banks in Indonesia, it can be concluded as follow: first, the loan growth of foreign banks is stable during the crisis because those foreign banks in Indonesia serve as more 'crisis-mitigating impact' for their respective parent bank. Second, during the crisis, especially on foreign banks, profitability and liquidity weaken the influence of the crisis on the loan behavior, as more foreign banks being more cautious in lending during the crisis. For further research, there needs to be more specifications on the loans variables, for example, consumer loans, working capital or investment

\section{ACKNOWLEDGMENT}

I would like to thank Bank Indonesia for the initial data collection.

\section{REFERENCES}

[1] Bank Indonesia, (2010) "Krisis Global dan Penyelamatan Sistem Perbankan Indonesia," Jakarta.

[2] Bank Indonesia, (2009). "Laporan Pengawasan Bank Tahun 2009," Jakarta.

[3] De Haas, R. and van Lelyveld, I. (2010). "Internal Capital Markets and Lending By Multinational Bank Subsidiaries" J. Finan. Intermediation, vol 19, no 1, pp. 1-25.

[4] De Haas, R. and van Lelyveld, I. (2014). "Multinational Banks and The Global Financial Crisis: Weathering The Perfect Storm?" Journal of Money, Credit, and Banking. vol 46, issue. 1, pp. 333-364.

[5] Pontines, Victor and Siregar, Reza. (2012). How Should We Bank With Foreigners? An Empirical Assessment of Lending Behaviour of International Banks To Six East Asian Countries. Centre For Applied Macroeconomic Analysis. Working Paper 4.

[6] Silalahi, Tumpak. Wibowo, Wahyu Ari. dan Nurliana, Linda. (2012). "Impact of Global Financial Shock to International Bank Lending in Indonesia", Buletin Ekonomi Moneter dan Perbankan, vol 14 no. 2, pp. 77-114.

[7] Allen, Franklin., Jackowicz, Krzysztof., and Kowalewski, Oskar. (2013) "The Effects of Foreign and Government Ownership On Bank Lending Behavior During A Crisis in Central and Eastern Europe". Wharton Financial Institutions. Center Working Paper No. 13-25.

[8] Raz, Arisyi F. Indra, Tamarind P. K. Artikasih, Dea K. dan Citra, Syalinda. (2012).“Crisis Keuangan Global dan Pertumbuhan Ekonomi: Analisa Dari Perekonomian Asia Timur". Buletin Ekonomi Moneter dan Perbankan, vol 14, no 2, pp. 37-58.

[9] Choi, Jung Moon., Eva Gutierrez, dan Maria Soledad Martinez Peria. (2013). "Dissecting Foreign Bank Lending Behaviour During The 20082009 Crisis. Journal of Finance and Pivate Sector Development Team". Policy Research Working Paper 6674.

[10] De Haas, R. and van Lelyveld, I. (2006). "Foreign banks and credit stability in Central and Eastern Europe. A Panel data analysis" Journal of Banking and Finance, vol 30, no. 1, pp. 1927-1952.

[11] Eken, Hasan Mehmet., Huseyin Selimler, Suleyman Kale, Veysel Ulusoy. (2012). "The Effect of Global Financial Crisis on The Behaviour of European Banks: A Risk and Profitability Analysis Approach" ACRN Journal of Finance and Risk Perspectives vol. 1, issue 2.

[12] Cull, Robert., Maria Soledad, and Martinez Peria. (2013). "Bank Ownership and Lending Patterns During The 2008-2009 Financial Crisis: Evidence From Latin America and Eastern Europe”. Journal of Banking and Finance, vol. 37, issue 2, pp 4861-4878.

[13] Brooks, Chris. (2008). "Introductory Econometrics for Finance, Second Edition" Cambridge: Cambridge University Press, Pp 487-509

[14] Gambacorta, Leonardo and Marques-Ibanez, David. (2011). "The Bank Lending Channel: Lessons From The Crisis". Monetary and Economic Department. BIS Working Papers No 345.

[15] Bebczuk, Ricardo. Burdisso, Tamara. Carrera, Jorge. and Sangiácomo, Máximo. (2010). "A New Look Into Credit Procyclicality: International Panel Evidence". Central Bank of Argentina, Buenos Aires. BIS CCA001-2010.

[16] Guo, Kai. and Stepanyan, Vahram. (2011). "Determinants of Bank Credit in EMEs", Working Paper 11/51. IMF.

[17] Mohanty, M. S., Schnabel, Gert and Garcia-Luna, Pablo. (2006). "Banks and Aggregate Credit: What is New?" BIS Papers No 28. 